\title{
From a National University to a National Higher Education System
}

PAVEL ZGAGA ${ }^{1}$

$\approx$ The article analyses the conceptualisations and gradual transformation of higher education in Slovenia from the 1980s to the early 1990s, i.e., during the period of profound social and political changes leading to the proclamation of the independent Republic of Slovenia in 1991. The broad public debate on the future of education in general was an important part of the awakening of civil society in the 1980s. In the specific field of higher education, intensive discussions led to the demand for a new and comprehensive development strategy. Given the profound transformation of higher education that took place during this period, this subject has been unjustifiably poorly researched. The article therefore tries to contribute to partially filling the gap, and at the same time to stimulating further research. Based on the study of archive material, the present analysis concludes that the most important innovation of this period can be defined as a gradual conceptual and then normative shift from a national university to a national higher education system.

Keywords: higher education system, history, Slovenia, transition, university 


\section{Od nacionalne univerze do nacionalnega visokošolskega sistema}

PAvel ZGAGA

$\propto$ Članek analizira konceptualizacije in postopno preobrazbo visokega šolstva v Sloveniji od osemdesetih do začetka devetdesetih let, torej v obdobju globokih družbenih in političnih sprememb, ki so leta 1991 pripeljale do razglasitve samostojne Republike Slovenije. Široka javna razprava o prihodnosti izobraževanja je bila v osemdesetih letih pomemben del prebujanja civilne družbe. Na specifičnem področju visokega šolstva so intenzivne razprave pripeljale do potrebe po novi in celoviti razvojni strategiji. Če upoštevamo, da je prišlo v tem obdobju do temeljite preobrazbe visokega šolstva, je bila ta tema do zdaj neupravičeno slabo raziskana. Članek zato skuša prispevati k delnemu zapolnjevanju vrzeli in hkrati spodbuditi nadaljnje raziskave. Na podlagi preučevanja arhivskega gradiva ta analiza ugotavlja, da je najpomembnejšo novost tega obdobja mogoče opredeliti kot postopen konceptualni in nato normativni prehod $\mathrm{z}$ nacionalne univerze na nacionalni visokošolski sistem.

Ključne besede: Slovenija, tranzicija, univerza, visokošolski sistem, zgodovina 


\section{A brief history of higher education in Slovenia and the situation in the 1980 s}

In 1919, Slovenia gained its first university, the University of Ljubljana, and in 1975 the second one, the University of Maribor, began to emerge. However, only after 1990 can one speak of the creation of a higher education (HE) system with several institutions. The conceptual conditions for this shift are related to the discussions of the 1980 os. Given the profound changes that took place in HE during the period of so-called political transition, this subject has been unjustifiably poorly researched. The present article is therefore intended to partially fill the gap and to stimulate further research. The analysis is based on various sources, both published and accessible archival material. As a participant in these processes, I have also drawn on my own memories and old notes. Since this period of time is already half a century away, the contemporary reader, especially the foreign reader, requires an insight into the wider context. ${ }^{2}$ This remains somewhat incomplete within the limited scope of this article, but it is supplemented by references to historians and by footnotes.

Slovenia only gained its second university in 1975. At least until then, the word university was used as a singular noun in everyday language, ${ }^{3}$ i.e., the University of Ljubljana. The latter was founded in the newly established Kingdom of Yugoslavia in a ground-breaking period after the end of WWI (1919), but was in fact the result of decades of efforts by Slovenians to establish their own university within the former Habsburg Empire. It was thus born as the national university par excellence. For almost half a century, it was the only institution of its kind, so it was not necessary to regulate relations with other universities, but only with its 'members', the faculties. In the first decades, its existence was threatened several times, especially during WWII, but in the post-war period, it developed rapidly due to the need to 'rebuild the destroyed country and establish socialism. New faculties and colleges ${ }^{4}$ were created, initially outside the university, but gradually integrated within it. In the 1960s, when the period of renovation turned into modernisation, another university began to emerge: individual independent faculties, colleges and universities merged into the

2 Given the simplifications in many sources, it should be noted that the political system of Yugoslav socialist self-management was very different from, and in essential elements also opposite to, that for which the term (Soviet) communism is usually used after 1990. These peculiarities have created a specific political terminology that is probably incomprehensible to the average reader today (e.g. 'united work', 'pluralism of self-managerial interests', etc.). These specific terms are written in single quotation marks so that they can be distinguished from quotations from the sources used.

3 Slovenian language has the grammatical category of the dual; therefore, one could say that two universities are not yet the plural that would make up the system.

4 The 'high schools' (visoke šole) ran four-year programmes and the 'higher schools' (višje šole) twoyear programmes. In the translation we use the term 'colleges'. 
University of Maribor (UM). This institution took on almost all of the essential structural elements that had previously developed at the University of Ljubljana (UL), against the background of the European continental academic tradition. One of the prominent features in the post-war period was the fragmentation of the institutions: the emphasis was on relationships between independent faculties, with the rectorates only having the role of coordinator of the 'higher education institutions ${ }^{6}$ (HEIs). The question of a coherent national system was neglected. ${ }^{7}$

We cannot go into the many legislative changes here, but it should be mentioned that in the Slovenian Higher Education Acts of 1965 and 1969, the term university was already used in the plural, despite the fact that there was only one such institution. The 1969 law defined it as an "obligatory community of faculties" and a "legal person" (just as the faculties had been before), but also allowed colleges to "merge into associations of higher education institutions" (Official Gazette SRS, 1969, par. 3). It was on this basis - with the amended law of 1975 (Official Gazette SRS, 1975) - that the request for the establishment of the UM was formulated and implemented.

The second Slovenian university was founded in fundamentally different times than the first. In the mid-1970s, the so-called 'liberal' period (1965-1974) ended and the 'leaden' period (1974-1986) in the history of socialist Yugoslavia began. The conflict between the 'hard' and the 'soft' line, which gradually became articulated in the post-war period after the split with the Soviet Union (1947), turned noticeably in favour of the 'soft' line from the mid-196os onwards. In the foreign political context, this change was reinforced by the 1968 attack on Czechoslovakia by the Warsaw Pact, which Yugoslavia openly condemned. "It was a time of 'relaxation and search', which manifested itself in different ways in the Yugoslav republics" (Čepič, 2010, p. 9). The 'liberal forces' became stronger especially in Slovenia, Serbia and Croatia. In Slovenia, the liberalism of the time meant "more political pluralism between and within the existing political organizations” (Repe, 1994, pp. 53-54). ${ }^{8}$ Economic policies focused on a combination of the recognition of market economy principles and intervention by the socialist state; domestic politics was characterised by decentralisation

5 In everyday language, the term university was often understood in the narrow sense of the rectorate.

6 The legislation of that time defined HEIs as faculties, art academies, high and higher schools, while a university was a community (association) of faculties.

7 Until the early 1960 s, the field was regulated by the federal General Law on Universities (1954), and new HEIs were established by special laws.

8 The League of Communists (LC; Communist Party until 1952) was the leading socio-political organisation' according to the Constitution, but it was not the only one; the others (represented in the Federal and Republic Assemblies) were the Socialist League of Working People, the Union of Trade Unions, the Union of Youth, and the Union of Combatants. The Republics were federal units with a high degree of autonomy. 
and greater independence (and responsibility) of the republics; foreign policy was characterised by the non-aligned movement (with the countries of the Third World) ${ }^{9}$ and cooperation with both the West and the East, while cultural policy allowed somewhat greater freedom of thought and artistic and scientific creation. Such 'liberalism' turned away radically from the classic Soviet concept of socialism and promoted modernisation, especially in the more dynamic sectors of the economy, which required a better-educated workforce.

The period of 'liberalism' did not eliminate the existing domestic political rivalries in Yugoslavia, but it did strongly shape life until the political showdown with 'liberal deviation' (Repe, 1994, p. 55), which was followed by a new Constitution (1974). It brought a kind of compromise between the political currents in the Federation. It seemed that a new concept of political balance had been achieved, as it had been in its infancy since the 1960s: "Yugoslavia became a union of states instead of a federal state, yet with control mechanisms guaranteeing the dominance of the centre" (Repe 1994, p. 53). Among historians, it is still debated whether the conflict of the time was really overcome, or whether it was only a milestone from which the way led straight to the dissolution of the Federation (Čepič, 2010, p. 12).

An integral part of these processes was the student movement, which unexpectedly erupted in June 1968 and then became more articulate (albeit in very different ways) at the universities of Belgrade, Zagreb and Ljubljana. In Slovenia, the sympathies of professors and students tended towards the liberals, but not without critical reflection and the avoidance of radicalism and open conflict. Probably the most important achievement - and at the same time the biggest difference with organisation of students in the rest of the Federation was the dissolution of the official Student Union of Slovenia (as an integral part of the Yugoslav Student Union) and the creation of a new organisation called the Student Community (1968). This new organisation was characterised by a commitment to political pluralism and organisational autonomy. The movement introduced important new topics into domestic debates on areas such as freedom of speech, minority rights, feminism, multiculturalism, student communes, environmental protection, etc. (see Pivec in Čepič, 2010, pp. 295-304). It was also associated with related movements in Western Europe. After the 'showdown with liberalism' (1972), the Student Community was abolished and the students were drowned by political coercion in a new organisation, the Union of Socialist Youth of Yugoslavia (1974) as a union of its republican organisations. Paradoxically, in Slovenia in the 1980s, this organisation was one of the cores of the so-called 'new social movements' (see Vurnik in Čepič, 2010, pp.

9 This attracted a considerable number of foreign students to Yugoslav universities from the 196os. 
347-364), in which 'alternative' themes inaugurated by the student movement of 1968-1972 flared up again, thus contributing to the conceptualisation of the political turn around 1990.

What was the general situation in HE after the period of 'liberalism'? As mentioned above, after 1975, there were two universities in Slovenia, which functioned as 'associations' of faculties and colleges. One might therefore expect that this would improve the conditions for new growth, but the data show exactly the opposite. Table 1 presents the trends in the number of students, graduates and staff over the three decades. ${ }^{10}$

\section{Table 1}

Number of students, graduates and teaching staff (1970-200o)

\begin{tabular}{ccccccc}
\hline \multirow{2}{*}{ Ac. year } & \multicolumn{3}{c}{ Students } & Year & Diplomas & $\begin{array}{c}\text { Teachers, } \\
\text { assistants }\end{array}$ \\
\cline { 2 - 4 } & UL & UM & Other & & & $\ldots$ \\
\hline $1970 / 71$ & 15,384 & $6 ., 248$ & - & 1971 & 2,304 & $\ldots$ \\
$1975 / 76$ & 19,477 & 8,605 & - & 1975 & 4,845 & $\ldots$ \\
$1980 / 81$ & 18,464 & 7,743 & - & 1981 & 6,494 & 2,582 \\
$1985 / 86$ & 20,378 & 9,223 & - & 1985 & 5,634 & 2,657 \\
$1990 / 91$ & 22,824 & 10,741 & - & 1991 & 5,439 & 2,568 \\
$1995 / 96$ & 32,577 & 12,888 & 486 & 1995 & 7,724 & 3,091 \\
$2000 / 01$ & 44,011 & 20,298 & 4,118 & 2000 & 10,447 & 4,800 \\
\hline
\end{tabular}

Note. Adapted from SURS and Zgaga, 2004.

The period of 'liberalism' coincided with growth in the number of both students and graduates: between 1970 and 1975, this number increased by almost a third. The proportion of part-time students was quite high, especially at the UM (at times representing almost half of the student body). The data show that this increase soon halted: between 1975 and 1980, enrolment actually fell by about $10 \%$. In the 1980 s, all major indicators point to stagnation: both the number of diplomas and the number of staff decreased. For this reason, I have called this period the "relatively lost years" (Zgaga 2004, p. 133). The lack of education that occurred during this period was acutely reflected in the working population in the 1990s. By that time, however, a belated but exponential increase in the number of students and graduates had already begun.

10 Full-time and part-time undergraduates are included. Courses for part-time students (employees: 'students through work') were held on weekends at $50 \%$ of full-time contact hours. About $40 \%$ of the teaching staff worked part-time. 
The 1980 os were perceived as crisis years by both the public and the HE sector. They were summarised in 1989 in an interview with the Rector of the University of Ljubljana, Professor Peklenik: “The [study] programmes expanded to almost unreasonable limits due to the method of financing. This had a rather negative effect on the quality and duration of the studies. [...] The current drop-out rate is between 40 and 50 percent. [...] This is also related to the pointless system of distribution of funds, when deans [...] have to negotiate individually with officials from the Slovenian Educational Community [Agency] and the government about the share that should belong to them" (Supplement, 1989 , p. 28). ${ }^{11}$

The 'leaden' period was marked by a major federal reform of the education system, i.e., the reform of career-oriented education (COE). Yugoslavia was not a strictly centralised state and in many areas decentralisation was gradually increasing. After the 1963 constitutional changes, the federal Ministry of Education was abolished and universities became the responsibility of the republics. With the constitutional amendment of 1974, the trend towards decentralisation intensified, but with noticeable signs of inter-republican friction (see Žagar in Čepič, 2010, pp. 231-256). This was also reflected in the field of education policy.

The decentralised regulation of education was also conditioned by different cultural traditions and languages of instruction. This was opposed by centralist forces, both political and cultural, especially after they had re-articulated themselves in the early 1980s, after Tito's death. These forces prepared the ground for the implementation of the policy that was later embodied by Slobodan Milošević. It was in this context that the provocative idea of common programme cores of education was born in $1983,{ }^{12}$ which was to apply to the entire Federation: In education programmes, e.g., in the curricula of literature, history, etc., each of the 'Yugoslav nations' was to receive a share corresponding to its share in the total population. In Slovenia, the proposal immediately met with strong resistance and further intensified criticism of the ideologically dictated concept of COE. We will therefore explain this concept in more detail below.

\section{Reform of career-oriented education and its critique}

The reform of COE began to be prepared in the mid-1970s after the elimination of the 'liberals'. The political starting point was established at the congresses of the LC (1974). The planned reform (cf. Lusa in Čepič, 2010, pp. 335-338) was primarily aimed at improving the educational structure of the

11 The Rector was not involved in the budget negotiations.

12 See, e.g., https://www.muzej-nz.si/si/izobrazevanje/1402. 
population. In HE, however, the politically motivated, preventive action against the student movement and the diverse critical circles of intellectuals could not be ignored.

There was a rush for the reform initiative everywhere, but not in the Socialist Republic of Slovenia (SRS). At the end of 1975, the expert study The Concept of Career-Oriented Education was published, but the Career-Oriented Education Act (COEA) was not adopted by the SRS Assembly until five years later (1980) (Official Gazette SRS, 1980). The concept included the abolition of the gimnazija (grammar school), the traditional preparatory space for university studies, which was accused of being elitist in character. The new upper secondary education was to provide five 'career-orientations' (e.g., 'natural-mathematical', 'socio-economic', 'physical education - defence', etc.). HE would upgrade secondary education to the 'most demanding qualifications' according to the 'career-orientation verticals'. A certificate of completed secondary school would be sufficient for enrolment; there would be no matura, the traditional 'maturity exam'. All of this greatly fuelled the controversy about university. At the universities, this controversy was further intensified by the abolition of the special Higher Education Act (HEA): between 1980 and 1993, HE was regulated by the COEA itself.

The political decision regarding COE triggered a surprisingly large public response (Zgaga, 2007, p. 69), as well as endless debates, both in political bodies and in the awakening civil society (Vurnik in Čepič, 2010, pp. 347-364.). The issue of the education system occupied a prominent place in public debates. Criticism was directed mainly against the abolition of the gimnazija and the matura, as well as against the idea of 'common programme cores'. This opened a front of a 'cultural war' in which many academics participated. Academics also contributed to the conceptual critique of the ideological concept of a 'comprehensively developed personality', on which the definition of the basic purpose of COE was based (Zgaga, 2016).

Critical voices were also reinforced by restrictions that became more widely and concretely experienced in the 1980s. The difficult economic situation brought with it a range of problems, from shortages of daily necessities to cuts in the education budget. Conscription was moved from university graduation to the end of secondary school. Enrolment in a number of degree programmes was restricted. In the second half of the 1980s, there was a shortage of advertised university places, partly because of the growing educational ambitions in society and partly because of the deteriorating employment opportunities. Thus, COE was implemented restrictively.

In 1982, an open letter to the leadership of the SRS was published in a then widely read weekly newspaper for intellectuals (Open Letter, 1982). The 
political leadership as well as the public were particularly shocked that it was signed by no less than 671 'public workers', mostly from the UL. The letter addressed the problem of developing the "intellectual potentials of our society" in a constructive tone, but sharply criticised the "artificial dismantling of existing or emerging quality pedagogical teams" (in gimnazija) and expressed "concerns over the unrealistic handling of the opportunities for optimal intellectual development of the most gifted section of the youth". In addition, it assessed "the irresponsible behaviour towards this part of the youth" as "at the same time irresponsible and extremely short-sighted also towards society as a whole and in particular towards our science". The letter concludes: "The success of the entire reform also depends on whether we succeed in raising the educational level of the lower level programmes, especially the former vocational schools, without lowering the educational level already achieved in the more demanding [secondary] schools".

'Oriented' programmes were adopted late. The first students enrolled in the new HE programmes in the 1985/86 academic year, when criticism of the conceptual justification and strategic purpose of COE was already widespread. Preparation of the postgraduate programmes was also delayed, but with the consolation that it would be another four to five years before the first graduates enrolled in them. Almost none of the stakeholders were satisfied with the 'renovation of HE. Reports from this period mention many problems: pressure from HEIs to extend programmes by a semester or two (in the hope of increasing funding); fears among academic staff that 'oriented' candidates would bring too little general knowledge; problems with the relevant 'verticals' between secondary and tertiary education; the 'narrow-mindedness' of HEIs in relation to the educational interests of young people, etc. New programmes were created in isolation within individual faculties and colleges, and work was uncoordinated and did not promote interdisciplinary integration, as the organisational structure of the university was fragmented. ${ }^{13}$ The call for a critical analysis of the situation as a basis for planning meaningful reform intensified both in academia and among the public.

The critique of COE thus gradually established a space in which a profound discussion could take place about what kind of education is needed for the future. Under the influence of this criticism, as well as in the atmosphere of the new political liberalisation that took place in Slovenia in the second half of the 1980 s (Repe, 2005, pp. 107-108), the reform of the COE reform gradually began.

13 The United Work Act (1976), another peculiarity of Yugoslav socialist self-management, deepened the fragmentation of HE: some faculties already functioning as legal entities were further subdivided into so-called 'basic organisations of united work in HE' (VTOZD) as legal entities. 
With amendments to the COEA, it was allowed first to complete secondary education with a final examination (1983), which was a step towards the legal redefinition of the matura (1989). These and other changes were related to the widespread belief at the time that society was in crisis and that Slovenia needed a clear strategy for long-term development. The crisis of the 1980s did not lead to lethargy, but offered an opportunity. This was also convincingly demonstrated in HE.

\section{Long-term development of higher education in Slovenia}

Significant shifts occurred in 1986. There were far-reaching personnel changes on the political horizon: in the Slovenian LC, the previous 'hard' line was replaced by a 'soft' one (Milan Kučan); at the same time, Slobodan Milošević became the head of the Serbian LC. The paths of further political development in the Federation diverged completely, and the conflicts began to deepen. The changes in the political forums in Slovenia were accompanied by a spontaneous process of democratisation, accelerated by the so-called 'new social movements' (Vurnik in Čepič, 2010, pp. 347-364). A fundamental shift was also taking place in education policy: The new Minister of Education gave the green light to the 'reform of the reform'.

The implementation of COE was accompanied by evaluation studies, on the basis of which the Ministry prepared the Report on the Transformation of Education (Assembly Reporter, 1986, pp. 1-13) and submitted it to the SRS Assembly. The report chose "the role of education in the social development of Slovenia" as its starting point (Ibid., p. 1). In its general section, there is a "sharp rejection" of the concept of common programme cores as "a kind of supranational curriculum that would cover the competence of the Republic in an area as important for the development of the nation as the mother tongue" (Ibid., p. 10). HE was dealt with in a separate chapter, while the idea of introducing a "final and advanced [nadaljevalni] examination", which would be a ticket to HE (the term matura was not yet used) stands out in the general section.

The chapter on HE (Ibid., pp. 10-13) begins with an analysis of the innovations in curricula. The main point highlighted is that "even in the new structure, there are no interdisciplinary and multidisciplinary programmes, [which] indicates the absolute dominance of the institutional [i.e., faculty] and disciplinary divisions", while "the number of subjects has increased beyond the critical limit". On the positive side, the report notes that "the process of constituting special professions in Slovenia (design, transportation, preschool education, computer science and informatics, some process technologies, etc.) has begun", but points to the extremely complex process of approving new programmes in 
the then system of 'self-managerial communities of interest'. The report further states that "the partial aspect and monopoly of the school over the university prevailed in our legislation and in the practice of higher education", and then supports the emerging "development strategy of Slovenian higher education".

What "development strategy" was meant? In 1984, the universities and the Chamber of Commerce organised a consultation that concluded, among other things, "that a thorough study of the position and role of the university in the long-term development of Slovenia should be carried out" (DRVŠ, 1986, p. 3). The following year, a proposal for the multi-year research project LongTerm Development of Higher Education in SR Slovenia (DRVŠ) was prepared within the framework of the then Centre for University Development (CRU). ${ }^{14}$ Discussions related to this project are today the main source for the analysis of the conceptual design and shifts of that 'transitional' period.

The project deals with the treatment of Slovenian HE from the perspective of the global "university crisis", which is the result of "rapid changes in development" and "complex and fatal contradictions" (DRVŠ, 1986, pp. 11-12) that occur in modern societies. In these contradictions, processes in broader society are linked to those within the university. The design of the project attests to the fact that the authors were well acquainted with the analytical literature of the time on HE development. One of the neuralgic points of the "university crisis" was identified as the transition from elite to mass higher education, which had been a prominent topic of international discussion since the 1970s (Trow, 1973). "The rapid opening of existing universities was not enough to meet the 'needs for higher education"'; "educational work was not based on the scientific research work of professors"; "universities actually became 'schools' resembling other [secondary schools]" (DRVŠ, 1986, p. 15), etc.

As we have seen above, the trend of HE massification started in Slovenia around 1970, but was stopped early. In the liberalised political atmosphere of the mid-198os, the draft DRVŠ noted that "the effort to reduce the number of graduates $[\ldots]$ meets resistance outside the university and within it" (p. 15): "democratic forces fighting for social equality" cannot agree "to the criteria of employment, 'efficiency', etc., emphasized by capital and the state in the new situation" as the only criteria; the role of university education must be seen as "broader than pragmatic interests" (Ibid., p. 16), etc.

The authors of the project were aware that "views on the university and its further development are not uniform", partly due to the fact that projections on the development of the university were "not objective and scientifically

14 The CRU was established in 1970 and played an important role as the UL's research, development, information and advisory unit; unfortunately, it was abolished by the UL leadership in 1995. 
research-based". The differences are partly due to "recent reform interventions in educational programmes", which have shown that "preparations for the transformation of the university have been inadequately planned". All of this "points to the need for a different approach, for thorough, in-depth analyses" (Ibid., p. 17). This is the task the project set out to accomplish.

\section{From the consideration of a national university to the conceptualisation of a system}

The implementation of the DRVŠ project began in the second half of 1986. The work relied on external collaborators, almost exclusively university staff, "who, because of their $[\ldots]$ experience $[\ldots]$ are familiar not only with the problems of our university, but also (though often only partially) with the work of other universities, especially European and American" (DRVŠ, 1987, p. 8). The work was organised into seven groups, and 135 researchers were involved (Ibid., p. 10). This was both a strength and a weakness of the project. The first research report states that "most of the researchers were confronted for the first time with the problem of systematic study of the university" (Ibid., p. 10), and that problems arose "due to the lack of specialists who systematically study the modern university" (Ibid., p. 15). The staff of the CRU, which was supposed to be the institutional bearer of the project, was involved only to a limited extent, and even these staff members were assigned mostly administrative tasks. Despite the late start of the project, the initial results were promising: in six months, 42 papers (1400 pages) were produced on a range of topics, from university autonomy and organisation, to teaching, research and support services. "We have never had so much useful information on the developmental problems of our university on paper" (Ibid., p. 13).

In the Slovenian library information system COBISS, there are 28 bibliographic units, mostly research reports, documenting the progress of the project (1986-1991); unfortunately, not all of them are available in public libraries today. Judging from this database, the project peaked in 1988 (12 units) and 1989 (10 units). Initially, the project attracted a large number of collaborators; later, according to COBISS, their numbers declined sharply. However, an already unsystematic review of the Slovenian professional press of the time ${ }^{15}$ shows that the intensity of the public debate on HE increased significantly in the late 1980 os. DRVŠ was not able to realise some of its academic ambitions (e.g., it did not lead to the constitution of HE studies as a new field of research in Slovenia), but it had a great social and political impact: it strongly stimulated discussions

15 For example, the journals Sodobnost and Teorija in praksa; the newspaper Naši razgledi. 
about $\mathrm{HE}$ and thus contributed significantly to the starting point for a new $\mathrm{HE}$ system in the early 1990 .

A resounding national conference was organised in November 1987, which can be considered the culmination of the project. The working material entitled Basic Positions and Alternatives for the Long-Term Development of the University and Higher Education in Slovenia was prepared by the project group (DRVŠ, 1988, pp. 69-115). The material emphasises that it does not bring "full agreement" on open questions: since agreement "could not always be achieved" (Ibid., p. 71), the material also contains "variant proposals" discussed by academic staff and (rarely) students, as well as some prominent Slovenian politicians, but only a few entrepreneurs.

The introductory speeches reflect, on the one hand, the political and strategic frictions in the Federation at the time and, on the other hand, the emphasis on the organisation of the university as well as on institutional autonomy, a concept that did not exist in the official documents. Deputy Prime Minister Boris Frlec pointed out the "paradox of the whole construction of the school as an enterprise" (Ibid., p. 34), which was a direct criticism of the basic conception of COE. He went on to emphasise that the university is not an "enterprise", that it is "always also something 'other', and it is the latter that gives it its characteristic trait" (p. 38), concluding that this was something that needed to be discussed. What a university is and what it should be in the future thus became one of the guiding questions of the debate. In a given political atmosphere, the need for a reformulation of the relationship between (another) state and (another) university was dictated: "The university outside the political relationship is [...] a pure illusion, and with it the notion of higher education autonomy as a distance from a social environment, however structured" (Ibid.). For Andrej Marinc of the Presidium of the SRS, it was crucial under the given circumstances "to promote the creative freedom of individuals and groups and thus also the responsibility for their own and common development" (Ibid., p. 45). "Despite the aggravations and conflicts [in Yugoslavia], the path must lead to progress, and it is in this sense that I understand the need for the mutual influence of society on the development of the university and of the university on the development of society" (Ibid., p. 46). Such accents would not have been possible before 1986.

The President of the Project Council, Professor Fabinc, ${ }^{16}$ summarised the major strategic issues. The renewal of HE "takes place in the historical period of transition of our society from an extensive to an intensive economy" (Ibid., p. 47). How does one find the right path of transition? "There is no universal

16 Rector of the UL (1981-1985) and member of the SRS Presidency from 1986. 
model of universities. A true university is the result of a long creative process of its social environment" (Ibid., p. 49). The reduction of the university to an educational function and the neglect of its research function "pushed the university into the profile and operating conditions of a secondary school" (Ibid., p. 50). At a time when science was becoming a key factor in the "race in the world economy", in Slovenia "the interests of the university and other important research units are in conflict" (Ibid., pp. 51-52). This raised questions of organisation. "The only possible basis for self-organization and for regulating the position of the university in society" must not be based on "the closure and renewal of outdated monopoly tendencies, but above all on the basis of openness and acquired quality of work" (Ibid., p. 54). The reform must take into account, on the one hand, the "strengthening of the faculties' professional responsibility for their integrated educational and research programmes", and, on the other hand, the decision-making of "new central university bodies which take over part of the professional responsibility hitherto borne by non-university [i.e., political] institutions" (Ibid.).

The discussion at the conference did not produce any significant new conceptual emphases. There were, however, some differences, mainly related to the environment from which the speaker came: from a faculty, college or academy of arts; from the field of natural, technical or social sciences or humanities; from Ljubljana or Maribor. A great deal of attention was paid to the future organisation of $\mathrm{HE}$ and the principle of university autonomy, i.e., the abolition of the regulation that "deprives the university of its role as a subject of decision-making" (Ibid., p. 74). The changes must go "in the direction of greater interconnection of university units in terms of basic activities and in the direction of creating a university as an entity" (Ibid., p. 109). A consensus was reached on this issue, but it also became apparent that "several possible theoretical alternatives [...] can be identified in resolving the relationship between 'faculty', 'high' and 'higher school' education" (Ibid., p. 86). The existing relations of 'university members' proved to be the biggest obstacle in conceptualising the elimination of university fragmentation and the transition to an 'integrated university'; this obstacle persisted until the late 1990s (Zgaga, 2007, pp. 77-79; Zgaga \& Miklavič, 2011, pp. 17-18).

The decision on this obstacle was expedited by the political processes and bodies of the time, although not overnight. In May 1988, six months after the national conference of the DRVŠ project, the SRS Assembly discussed a proposal for a thorough intervention in the COEA, as well as the initiative of both universities to restore a special HEA. The position was taken that "with any significant changes it is necessary to wait for the results of the research 
projects in the field of higher, secondary and adult education" and "not to interfere with the basic conception of the act"; however, those "issues on which we agreed earlier and unified based on the results of the evaluation research can be solved" (Assembly Reporter, 1988, p. 44). In particular, this was a return of the matura to the education system, as well as some changes in the role and tasks of universities.

The legislative process took a year and the amendments were adopted by the Assembly in June 1989. As early as February 1989, a group of experts was formed to prepare a new concept for the matura. After intensive work, its final report (Pedagogical Worker, 1989a, 1989b). proposed quite detailed outlines of an externally assessed examination. The report contained the main arguments for its reintroduction into the system and also contributed to the somewhat later return of the gimnazija. ${ }^{17}$ The system of COE began to disintegrate.

Concurrent with the submission of a government proposal to amend the COEA to the SRS Assembly, the two universities submitted a request for a new law on HE, "recalling the need for specific and comprehensive legislation on higher education". The Assembly adopted the request, adding "that a special law $[\ldots]$ would regulate the $[\mathrm{HE}]$ system more comprehensively and remedy the deficiencies of the present legislation [...] when the research results of the [DRVŠ] project were incorporated into that law". It suggested "that the universities, as the proposers for the enactment of the [HE] law, shall prepare all the conceptual bases for the proposal [...] in cooperation with the [government], which should be the proposer for the law". (Assembly Reporter, 1988, p. 44).

The ball was now in the universities' court; however, the process going forward was anything but straightforward. To the reasons already outlined, one must add the increasingly turbulent political situation that led to the independence of the Republic of Slovenia (RS) and the brief war with the Yugoslav Army (June 1991) after the first multiparty and democratic elections (April 1990). The university preparation of the starting points for the HE law was clearly summarised by Albin Igličar (1992, pp. 1197-1198):

"Following the decision to regulate higher education outside the CareerOriented Education Act, the first comprehensive theses of the law on the university were prepared in October 1989." Before the text prepared by the representatives of the two universities was submitted to the political authorities, "a discussion took place at the universities at the end of 1989. Due to the great heterogeneity - especially of the University of Ljubljana - the theses did not find

17 They were reintroduced in January 1990; in two, the International Baccalaureate (IBO) was experimentally introduced in September. The national matura was conducted on a trial basis in 1994, and frontally in 1995, as stipulated by the 1989 amendments. 
general consensus in university circles. Therefore, the drafting of a new law was temporarily suspended. In the following year, the new leadership of the University of Ljubljana tried to reach compromise solutions by making numerous changes to the original theses, but they destroyed the consistency of the original draft law. Later, a new working group of the government and the universities was formed, which prepared the most general starting points for the new university law, but none of these texts got beyond the ministry line or were discussed in a government or assembly session." Igličar concluded: "It seems that the main reason why the university itself finds it very difficult to formulate generally accepted theses of higher education law lies in its extraordinary heterogeneity, in the 'digging in' of each faculty, college and academy of arts in their own interests and acquired rights. In such a situation, the effort to find compromise solutions becomes a 'rotten compromise', which then satisfies no one."

\section{Conclusion: Adoption of the HEA (1993)}

In the heated atmosphere of the late 1980s, the debate stimulated by the DRVŠ project contributed to the critique of the existing regime, to the confrontation of different analyses, and to attempts at a new conceptualisation of HE. Such confrontation had a significant impact on the gradual establishment of a new regulation of the education system in the newly born RS. Of course, this path was not straightforward.

Slovenia's independence would not have been possible without the great commitment of civil society, in which students and professors were often at the forefront. This was also reflected in the composition of the SRS Assembly after the first multiparty elections. Now critiques and analyses had to be 'translated' into normative form. The new basic norm for HE was introduced in December 1991 by the Constitution of the RS (1993), Article 58: "State universities and other institutions of higher education shall be autonomous. The funding of these institutions shall be regulated by statute." With this short definition, the debate about what autonomy means had just begun, and the road to regulating the funding of institutions was long and arduous (Zgaga, 2007, pp. 77-82).

In the DRVŠ project materials and in various discussions from the late 1980s, there is a great deal of criticism: of the concept of COE and its negative impact on HE, and of existing practices within HE. These critiques were justified in many ways and contributed to the gradual formation of new concepts, but one cannot overlook the moments in which their particular, separate point of view is expressed, their 'blind spot': the lack of self-critical introspection, such as, for example, Bourdieu (1984) offered to the international debate exactly in 
those years: the academic space is not only a space of dialogue and the search for truth, but also a space of power, fuelled by academic reputations and careers.

The 'blind spot' reinforced a persisting fragmentation of HE. Fragmentation prevented both the synthesis of different discussion outcomes and the transition from research to policy making. Particular academic interests resisted both systematic, unbiased, critical research on HE and a unified approach to negotiations with political authorities. Each was intent on its own gain. Thus, the question of the relationship between independent faculties and colleges was foregrounded, while the question of the national HE system was ignored. Selfcritical self-reflection, which remained marginal during this period, would demand more: the zeitgeist demanded not only a different state, but also a different university. This was not possible, however, without at least a relative reordering of the balance of power in academia.

For a long time after WWII, the university was a 'community' of HEIs, not a sui generis institution (which was the case when the UL was founded in 1919). Even after 1975, when the word university was no longer used in the singular, no need was seen "to introduce a strictly institutionalized coordinating body between the two universities" (DRVŠ, 1989, p. 53). With the reorganisation of HEIs (VTOZD; see note 16), COE further increased their organisational and academic fragmentation. The conceptual change from the (otherwise obligatory) 'community' of HEIs to the university was one of the central conditions for further development, but it was also a condition for the conceptual change from the national university to the national HE system.

After the collapse of the first government coalition and the formation of a new government in the spring of 1992, the coordination of the starting points for the new law intensified from mid-1992. As early as December 1992, the government submitted a harmonised Proposal for the Higher Education Act with Theses (Assembly Reporter, 1992, pp. 65-77) to the Assembly. The explanatory memorandum referred to the European and international trends of the time: the new law "comes into being at a time when European integration processes dictate the convergence and unification of higher education, which faces new development tasks in each national environment". However, European traditions have "shaped diverse systems, none of which can be considered the sole model". International cooperation "is today conditioned above all by the mobility of students and the approximation of the qualities of graduates, that is, by the comparability of degrees", which "cannot be achieved by administrative means alone" (Ibid., p. 66). The proposal underlines the importance of academic mobility. ${ }^{18}$ The Erasmus programme was already known at the time; Slovenia only

18 The idea of a "European student" was discussed in the DRVŠ $(1988$, p. 93) project. 
joined it in 1999, but had been integrated into the Tempus programme since the early 1990s. Besides the concepts that emerged mainly from the strategic ideas of the then European Community, others are also recognisable in the proposal, e.g., those promoted by the Magna Charta Universitatum (1988), which was also signed by Slovenian universities. In short, the new law was to "enter the field of European systems and diversity". Seven years later, Slovenia was in the first group of countries to sign the Bologna Declaration (1999).

Key concepts emphasised in the bill (see Ibid., pp. 66-67) include "securing the autonomy of universities and colleges" and "reorganizing the university from the previous loose community into a traditionally understood university". Related to this is the principle of deregulation: "delimitation of state competences from academic self-management and the formation of a body of experts" to deal with strategic issues (Council for Higher Education of the Republic of Slovenia). ${ }^{19}$ Among the issues discussed at length in recent years are the definition of the matura as an entrance ticket to $\mathrm{HE}$, the integration of teaching "with compulsory scientific research", and the "differentiation of university and higher professional education" (i.e., bifurcation, which should allow broader access to studies and better-qualified graduates). The proposal includes the hitherto non-existent right to "one year of in-depth training [...] every six years" (sabbatical), but also mentions "the possibility of multiplying and pluralising higher education centres in the future", which would expand study opportunities as well as introducing "competitiveness into higher education".

The HEA was passed by the Assembly in three phases in December 1993. In June 1992, I replaced my previous work at the UL's Faculty of Education with work as the State Secretary at the Ministry of Education and accepted responsibility for coordinating and adopting this Act. Therefore, the research paper must shift to les memoirs at this point.

\section{Acknowledgement}

The article is based on research work within the framework of the research programme Systemic Aspects of Educational Strategies and Encouraging Social Inclusion in Education ( $\left.\mathrm{P}_{5}-0126\right)$, financed by the Slovenian Research Agency (ARRS). 


\section{References}

Assembly Reporter. (1986). Poročilo o preobrazbi vzgoje in izobraževanja [Report on the transformation of education]. Poročevalec Skupščine SRS, No. 27.

Assembly Reporter. (1988). Sklep Skupščine SR Slovenije ob obravnavi zahteve za izdajo zakona o visokem šolstvu [Resolution of the Assembly of the Socialist Republic of Slovenia on consideration of the request for the issuance of the Higher Education Act]. Poročevalec Skupščine SRS, No. 16. Assembly Reporter. (1992). Predlog za izdajo zakona o visokem šolstvu s tezami - ESA 759 [Proposal for the issuance of the Higher Education Act with theses - ESA 759]. Poročevalec Skupščine RS, No. 27. Bourdieu, P. (1984). Homo academicus. Minuit.

Constitution of the Republic of Slovenia. (1991). Uradni list RS, No. 33.

Čepič, Z. (2010). Slovenija - Jugoslavija, krize in reforme 1968/1988 [Slovenia - Yugoslavia, crises and reforms 1968/1988]. Inštitut za novejšo zgodovino.

Igličar, A. (1992). Zakonska ureditev visokošolskega izobraževanja [Higher education legislation].

Teorija in praksa, 29(11-12), 1197-1206.

DRVŠ. (1986, October). Projekt dolgoročnega razvoja [Long-term development project]. Center za razvoj univerze.

DRVŠ (1987, October). Projekt dolgoročnega razvoja: prvo poročilo [Long-term development project: First Report]. Center za razvoj univerze.

DRVŠ. (1988, January). Projekt dolgoročnega razvoja: gradivo s posveta. Dolgoročni razvoj visokega šolstva $v$ SR Sloveniji [Long-term development project: Material from the conference The Long-Term Development of Higher Education in SR Slovenia]. Center za razvoj univerze.

Official Gazette SRS. (1969). Zakon o visokem šolstvu [Higher education act]. Uradni list SRS, No. 9. Official Gazette SRS. (1975). Zakon o visokem šolstvu [Higher education act]. Uradni list SRS, No. 13. Official Gazette SRS. (1980). Zakon o usmerjenem izobraževanju [Vocational education act]. Uradni list SRS, No. 11.

Open Letter. (1982, July 9). Odprto pismo Predsedstvu SR Slovenije, Predsedstvu CK ZKS in Predsedstvu RK SZDL [Open letter to the Presidency of the Socialist Republic of Slovenia, the Presidency of the Central Committee of the Communist Party of Slovenia, and the Presidency of the Republican Conference of the Socialist Alliance of the Working People of Slovenia]. Naši razgledi. Pedagogical Worker. (1989a, September 11). Končno poročilo delovne skupine Zaključni izpit in matura [Final report of the working group Final Exam and Matura] [1]. Prosvetni delavec, No. 12. Pedagogical Worker. (1989b, September 25). Končno poročilo delovne skupine Zaključni izpit in matura [Final report of the working group Final Exam and Matura] [2]. Prosvetni delavec, No. 13. Repe, B. (1994). The liberalization of Slovene society in the late 196os. Slovene Studies, 16(2), 49-58. Repe, B. (2005). Slovene history - 2oth century. University of Ljubljana, Faculty of Arts. Supplement. (1989, June 24). Pogovor s kandidatoma za rektorja. Za razvoj znanosti sta potrebni kontinuiteta in stabilnost [Interview with the two candidates for rector. Continuity and stability are needed for the development of science]. Sobotna priloga, Delo, p. 28. 
Trow, M. (1973). Problems in the transition from elite to mass higher education. Carnegie Commission on Higher Education.

Zgaga, P. (2004). Analiza gibanj v strukturi študentov in diplomantov $v$ terciarnem izobraževanju (1981 - 2004). Raziskava za pripravo strategije razvoja Slovenije [Analysis of trends in the structure of students and graduates in tertiary education (1981-2004). Research for the preparation of Slovenia's development strategy]. University of Ljubljana, Faculty of education.

Zgaga, P. (2007). Higher education in transition. Reconsiderations on higher education in Europe at the turn of the millennium. Umeå University.

Zgaga, P., \& Miklavič, K. (2011). Reforming higher education in "transition". European Education, $43(3), 13-25$.

Zgaga, P. (2016). Education in the whirlwinds of "transition": On people who won freedom but must now learn how to enjoy it properly. Hungarian Educational Research Journal, 15(1), 34-53.

\section{Biographical note}

Pavel Zgaga, PhD, is Professor of Philosophy of Education at the Faculty of Education, University of Ljubljana, Slovenia. His main research areas are studies of higher education, including teacher education as a specific area within higher education, concepts and history of ideas in higher education, and (higher) education policy and reforms in the contemporary European context. 